\title{
The Enduring Fundamental Framework of Forest Resource Management Planning
}

\author{
Robert D. Tew, Thomas J. Straka*, Tamara L. Cushing \\ School of Agricultural, Forest, and Environmental Sciences, Clemson University, Clemson, USA. \\ Email: "tstraka@clemson.edu
}

Received August $9^{\text {th }}$, 2013; revised September $11^{\text {th }}, 2013$; accepted September $28^{\text {th }}, 2013$

Copyright @ 2013 Robert D. Tew et al. This is an open access article distributed under the Creative Commons Attribution License, which permits unrestricted use, distribution, and reproduction in any medium, provided the original work is properly cited.

\begin{abstract}
Forest resource management planning began in the United States at the turn of the nineteenth century with an emphasis on timber production, sustained yield, and maximum timber growth. A set of well-documented procedures, philosophies, rules, and understandings developed within the forestry profession on the reasons for and requirements of a professionallydeveloped forest resource management plan. For most of the next decade, this framework controlled the development of timber-oriented forest management plans. In the late twentieth century, the forest resource management plans became stewardship- or sustainability-oriented. A broader expansive framework that stressed sustainable forest management developed. However, the framework of both types of plans is fundamentally the same. The natural resource being manipulated is still timber and that is the variable the management plan still focuses on. The set of fundamental underpinnings to the forest management plan has not changed. We describe these underpinnings in terms of both types of forest management plan, as they have remained unchanged over time. Also addressed are the questions of who are the forest owners that plan and what are the differences in the type of forest management plans they prepare.
\end{abstract}

Keywords: Forest Resource Management Plan; Forest Resource Management Planning; Sustainable Forest Management

\section{Introduction}

Forest resource management planning began in the United States at the turn of the nineteenth century [1-3]. The earliest American foresters received their training in Europe and this classical training strongly emphasized timber production, sustained yield, and maximum timber growth [4-6]. Sustainability was always part of American forestry, but the early concept was one of sustained timber yield. Not only did sustained yield center on one product, but it usually meant sustained maximum yield of timber over time [7]. Foresters were concerned with "normal" forests that possess optimal stocking to produce the maximum amount of timber over time (called maximum mean annual increment) and even used normal yield tables [8].

Early American forest management planning consisted of measuring, inventorying, and projecting forest stands in terms of this optimum normal forest. The earliest management plans were developed for large private forest holdings and national forests [9-12]. The idea of sus-

${ }^{*}$ Corresponding author. tainability slowly changed over the nineteenth century from one of timber to recognition of other forest products in terms of optimality [13]. Wildlife, in particular, gained importance [14]. By the late twentieth century, multipleuse (management of an array of natural resources, not just timber) and forest stewardship (of all natural resources) were the norm [15-17]. In the last few decades the concept of forest sustainability or sustainable forest management has moved to the forefront [18].

The concept of forest stewardship was developed by the United States Department of Agriculture (USDA) Forest Service as a model for forest sustainability on family forests in the United States [19]. Forest stewardship management plans are required before family forest owners can apply for federal cost-share funds to aid in forest management activities; this, and that the plans are usually free or produced at low cost, make the forest stewardship management plan very attractive to family forest owners [20]. The USDA Forest Stewardship Program was managed at the state level by the state forestry commission or division with federal funding [21]. This made the program have a "grass-roots" level of appeal. Forest 
stewardship required family forest owners to develop and implement a broad multiple resource forest sustainability-type forest management plan [22-24]. Most of the states developed guidelines and management plan standards that were tied to a general set of federal guidelines [25]. In the early twenty-first century forest stewardship management plans were one of the most widely accepted forest management planning tools of family forest owners in the United States.

A second influence was driving forest sustainability at the same time. Forest certification has become a major factor driving forest resource management towards a forest sustainability foundation [26-28]. Loss of biodiversity was a main concern at the start of the movement and the early focus was on deforestation of tropical rainforests, but the focus quickly became global [29-31]. A labeling process to identify tropical wood managed under sustainable forest management principles was developed by the International Tropical Timber Organization in 1988 [32-34]. This process is called eco-labeling and is a means to label products that indicated their environmental characteristics. In this case, the specific environmental characteristic is having been managed under sustainable forest management [35-37]. The idea is for consumers to then direct their purchasing power towards firms that manage their resources in an environmentallyfriendly manner [38-40].

Europe and North America had strong environmental regulations at the same time, and they generally covered both public and private forestland [41-43]. This did not satisfy some environmental groups and pressure developed for forest certification programs worldwide [44,45]. Pressure from different groups (like trade associations, environmentalists, and family forest owners) resulted in multiple forest certification schemes [44]. Examples are the Forest Stewardship Council, the American Tree Farm System, and the Sustainable Forestry Initiative. These are all widely-accepted programs and are examples of consumer-driven quasi-regulation [46-48]. That is, no government regulation gives these organization powers; their powers are fundamental and derived from the pocketbooks of consumers. They are destined to be a major contributory factor in the continuing acceptance and demand for sustainable forest management.

Today there are templates for proper construction of the various types of contemporary forest resource management plans. Many states have suggested outlines of items necessary to produce an acceptable forest stewardship management plan. The USDA Forest Service also has manuals on writing forest stewardship management plans. Certification bodies have produced forest management plan templates. One reason templates are necessary is the increasing complexity of forest management planning. Sustainable forestry requires a much broader, more complex plan [49]; at the same time the framework of the management plan has changed little [50].

The older timber-oriented forest management plan has always had a framework based on forest management and most always follows the process of describing the forest resource, measuring the forest resource, analyzing the resource, and allocating the resource [51,52]. The forest management plan always had a silvicultural basis, as silviculture was the tool used to manipulate the timber $[5,8]$, and, since timber is an asset, there was an expectation of forest economics also being a factor [53,54]. Also, expectations of forest resource management planners have not changed for key preparers of these plans, like consulting foresters [55], timberland investors [56,57], and family forest owners [58,59]. This identical basis can be seen from the earliest publications on management plans [60] to the most current publications on sustainable forest management [61].

Over time the traditional timber management plan evolved to include strong multiple-use foundations. Close observers will note those management plans are actually quite similar to contemporary sustainable forest management-type plans. Forest resource management plans, from the beginning, were subject to a strict set of expectations or requirements that were taught to foresters as rock solid fundamentals of the forest management planning process [62]. These have not changed over time and all forest management plans show evidence of these expectations. They often go unstated in the current template-based environment with computer-driven models spitting out results to fill tables in the plans. We discuss the long-standing requirements and framework for a forest resource management plan below. They are still crucial to the development of successful forest management plans.

\section{Reasons for Forest Resources Management Planning}

Forest resource management planning is a process that usually produces a written management plan. Forests are by nature long-term enterprises and the forest owner's expected future outcomes, like the forest condition 25 years from today, require actions today and over time to ensure these outcomes actually occur. The forest owner may have goals that do not involve timber directly, but virtually all forest resource management goals are achieved by manipulation of the timber resource. Thus, the silvicultural framework of the plan often is the engine that creates change and future outcome [63].

Without proper planning the forest owner can find future forest conditions that do not meet his or her goals. Planning ensures that timber products that are expected to be marketable are produced and, if profitability is a goal, that the timing of thinnings and harvests is optimal. 
It can ensure wildlife habitat develops to encourage selected wildlife species and it can ensure that the forest has recreation potential. Proper planning can even minimize the income and capital gains taxes paid at harvest or provide for a forest estate that spans the generations. The silvicultural prescriptions of today will determine the forest of tomorrow and without proper planning this forest cannot be expected to meet the forest owner's goals [64].

Forest resource management plans can vary from very complex and detailed written documents to a broad scheme stored in the forest owner's mind. Of course, there is no reason the mental plan cannot accomplish what a forest owner desires. However, the process involved in developing a written management plan greatly increases the likelihood that the forest owner will achieve the goals he or she has for the forest and allows for continuity of management when the owner passes away [65].

Planning starts with data gathering. Stand conditions will be determined. Resources will be identified. Problems will arise in this process and be identified (like improperly marked boundary lines or insect infestations). Once the forest information is collected it must be analyzed. This process may force the forest owner to reevaluate his or her management goals. This analysis will allow the planner to develop alternatives for managing the forest. The forest owner is the decision-maker and will select the alternatives that will be the basis of the plan. At this point the written document, the forest resource management plan, is developed. It details the activities that will occur on the forest: what activities, when they occur, and what is expected to occur as a result of the activities [66].

Foresters often use the words "goals" and "objectives" loosely. Most foresters will agree that the foundation to forest resource management is the forest landowner's management objectives. But sometimes the forester means landowner's goals when making that statement. What is the difference between goals and objectives (in a strategic planning sense)? Goals are broadly-focused and objectives are narrowly-focused. Goals can be abstract, while objectives must be solid. Goals can be stated as general intentions, while objectives need to be explicit. In planning, goals are general directions that can be ambiguous, while objectives must be specific and measureable. A goal will define what the organization is trying to accomplish and an objective will be a measurable result that supports the completion of a goal.

Forest resource management planning is not free. It involves time and money. A forest owner needs only the amount of planning necessary to achieve his or her goals. As long as the management goals of the forest owner are being met, the management plan is suitable. Detail can vary from the mental plan to a precisely written bound document. Like the goals for management, the scale of the plan is derived from the forest owner's needs [67].

Why plan? Why is forest resource management planning necessary? Plenty of forests receive no planning and end up fine. Some people are lucky and end up with good results in life without planning, but most people are not that lucky and need to plan for results. In Lewis Carroll's Alice's Adventures in Wonderland, Alice comes to a fork in the road and asks the Cheshire cat in a tree, "Which road do I take?” The cat asks her where she wants to go and Alice replies she does not know. "Then it doesn't matter”, says the cat.

If you don't have a plan you will never end up with the exact results you hope to achieve, except by pure luck. Achieving a specific outcome requires a specific goals and objectives; only then are you likely to end up where you hoped to be. Without this type of planning, the Cheshire cat is correct, "Then it doesn't matter."

\subsection{Eleven Reasons for Forest Management Planning}

Reasons forest owners need forest resource management planning are:

1) Planning requires collection of data on the forest and subsequent analysis of this data. It requires the forest owner to view the forest in terms of the stated goals and objectives. It can result in adjustment to the goals and objectives. This is, it requires an analytical look at the forest.

2) Planning identifies the opportunities and limitations on the forest. It identifies productive capacity and the incremental cost to utilize the capacity. It helps identify problems on the forest and forces the forest owner to consider addressing them.

3) Planning identifies the resources necessary to carry out the objectives of the forest owner. What are labor and capital needs? How are these needs likely to change over time? This analysis may require a change to goals and objectives.

4) Planning focuses on the long-term nature of forest management. Alternatives may have implications that impact the forest well beyond the lifetime of the current forest owner. The planning process forces the forest owner to think beyond his or her current problems in forest management.

5) Planning provides evidence of forest stewardship. The existence of a plan provides tangible proof that some sort of planning process has taken place. Another natural resource professional can determine this level of planning and attest to it if forest stewardship is ever questioned.

6) Planning provides the framework of forest sustainability. The plan will contain projected outputs and address the issue of sustainability of these outputs over time. 
For example, forest certification programs require sustainability of the forest and a management plan is the document certifiers look at to determine if this sustainability exists.

7) The planning process allows the forest owner and planner to understand the trade-offs between goals. The process identifies alternatives and then forces the forest owner to evaluate each alternative. Planning enhances the decision-making process. Planning can identify conflicting goals and encourage the forest owner to resolve the conflicts.

8) Planning allows for ensuring compliance with local, state, and federal regulations. Identifying all relevant regulations is part of the planning process, as is ensuring compliance with each regulation. If errors are made in conforming to regulations, the plan will provide evidence of a good faith effort for compliance.

9) Planning allows for the efficient scheduling of forest activities. A large forest can have a multitude of regeneration, harvesting, and silvicultural practices occurring simultaneously and continuously. Without a schedule these activities can hardly be performed on a costeffective basis. Scheduling can also point out equipment or labor shortfalls before they occur.

10) Planning allows for outputs to be matched to expected markets. Planners will have some expectation of future prices and markets. These expectations can lead to having outputs timed to take best advantage of markets.

11) Forest resource management plans allow for continuity of management. Forest owners or heirs may change foresters and the new forester needs to know what planning took place before his or her arrival. Forest owners change; management plans show where the former owner was trying to "take the forest". Forest resource management plans are continuous documents; dynamic not stable; and lead to management over the long-term that can exceed the lifetime of an individual forest owner or forester.

\subsection{Silvicultural Decisions}

Usually a forest resource management plan results in a "management regime" or schedule of silvicultural activities that are expected to take place on the individual stands in the forest [68]. If a forest stand is to be managed to produce outcomes consistent with the forest owner's goals, decisions must be made on how the silvicultural system and activities will be manipulated to produce desired outcomes [69]. In terms of basic silviculture these types of decisions involve:

1) Evaluation of the forest owner's management objectives and the future stand conditions expected. What does the forest owner expect the future forest to look like? What are the outcomes specified in the forest owner's goals and objectives?
2) What silvicultural systems will best achieve meeting the forest owner's objectives? Did the forest owner specify the use or nonuse of certain systems? Even-aged, uneven-aged, and group selection systems will certainly produce different future stand conditions.

3) Does the landowner favor certain tree species? Should the management regime encourage regeneration of these species? Thinning and regeneration methods will impact the future species composition of the forest. Shade-tolerance will determine future species mix to a degree and the silviculture applied will need to take this into account. Fundamental silvicultural practice is a foundation of a forest resource management plan.

4) Vegetation management can be used to release desired species and control undesirable species. This is an expensive option, but under the right conditions increased forest yield can make the investment attractive.

5) Fertilization is a second expensive option that can increase future yields. Depending on the financial expectation of the forest owner this can or cannot make sense.

6) Thinning is part of most management regimes. Some thinning is precommercial and is an expense to the forest owner. All thinning impacts the future stand conditions. What does the forest owner expect the future stand to look like? What forest products is he or she expecting?

7) Some forest owners specify conditions that require special actions. Wildlife objectives might require scattered food plots, snag trees, or a preference for mastproducing trees. Recreation objectives may require certain tree species or vistas.

8) Site preparation will have a huge impact on the resulting forest stand. Practices prior to timber harvest or during timber harvest can impact the future forest stand [70]. Site preparation is one of the crucial decisions; it is expensive and it has great impact.

9) How is the forest going to be regenerated? Planting controls species and density. Natural regeneration requires more skill to obtain desired species and density. Cost is a factor. Planting can be very expensive, while not planting can be expensive in terms of poor regeneration if nature does not cooperate.

\section{Who Prepares Forest Resource Management Plans?}

Forest management objectives, planning intensity and complexity, public participation in the planning process, and even standard management plan formats for forest resource management plans differ by the type of ownership. Different owners have different planning needs and resources (both on the ground and in their pockets to pay for the planning) [8]. Some planning processes, especially for public ownerships, stress public participation; some are financially-oriented and stress cash flow; and 
many are oriented to one natural resource (and not necessarily timber). In some respects they are very similar, in other aspects they can differ greatly [5]. Some of the differences come from regional aspects of timberland and others from differences in landowner management objecttives. The pattern of ownership, by region and owner type, gives interesting insight into these management plan differences [3].

There are 304 million ha of forestland and 208 million ha of timberland in the United States. The total land area of the country is $916,115,685$ ha. That means the United States is one-third forested and nearly a quarter of the nation is timberland. So, just over two-thirds of forestland is timberland [71].

What is the difference between forestland and timberland? Forestland is at least $10 \%$ stocked by forest trees of any size, or land formerly having such tree cover, not currently developed for a nonforest use. Timberland is forestland producing or capable of producing in excess of 1.4 cubic meters per ha per year of wood at culmination of mean annual increment. Therefore, timberland is a subset of forestland capable of growing commercial timber. There are two other categories of forestland: reserved forestland (land permanently reserved from timber production through statute or administrative designation, like wilderness areas and national parks and monuments) and other forestland (land not capable of producing 1.4 cubic meters per ha of wood annually under natural conditions). Reserved forestland occupies 30 million ha and other forestland occupies 66 million ha. This means timberland is $68 \%$ of forestland, reserved forestland is $10 \%$, and other forestland is $22 \%$ [71].

Forestland is fairly evenly distributed between the eastern and western US. In the East, it is fairly evenly distributed between the North and South. Nearly half of the public forestland is in the West. The North has just of over a quarter of public forestland and the South just under a quarter. Overall, $44 \%$ of the US forestland area is publicly-owned. This creates a clear difference in management by regions, since forest management intensity and timber production differ between private and public forestlands. Seventy percent of the western forestland is publicly-owned, while only a quarter of northern and only $13 \%$ of southern forestland is publicly-owned [71].

Public forestlands tend to receive public scrutiny, especially when forest management activities like timber harvesting and road construction are planned. The last few decades have seen the general public, environmental groups, forest industry, state governments, and other vested interests demand a greater voice in how publiclyowned forests are managed. Both legislative and judicial actions have impacted the planning process for these forests. Probably the federal forestlands are subject to the most scrutiny and they tend to have the most detailed, researched, documented, and complex forest resource management plans. Public participation is a requirement for the planning process and adaptive management is commonly used in plan implementation. In general, public input into the planning process is a hallmark of forest management on public forestlands. Of course, public lands are subject to changing government regulations over time, as courts, Congress, and the public interest interact over forest management issues. Some states (e.g., California, Oregon, Washington, and Maine) have very strong state-level forest practices acts that can impact reforestation, harvesting, aesthetics, water quality, and wildlife habitat. Many states without formal forest practices acts have adopted best management practices (BMPS) that serve as a minimum set of recommended forest practices. All of this involves forest resource management planning [3,5].

Timberland distribution in the US follows the same pattern as forestland except the trends are more pronounced (Figure 1). This is because much of the less productive forestland is in the West and does not meet the productivity standards to be classified as timberland. While the East has just over half the forestland area, it has over $70 \%$ of the timberland (Figure 2). However, over half of the timberland is public in the West, while just over $20 \%$ of the timberland is public in the East (Figure 3 ). The more productive timberland tends to be in private hands. These trends follow federal land ownership patterns and differences in regional timber types and productivity [71].

Most of the timber volume is in the East, especially the South, with the productive timberlands. But some regions of the West have very productive timberland and correspondingly high timber volumes. Forest resource management planning will reflect these regional differences. In the East the percent of timber volume tends to be less than the percent of timberland, while the opposite is true in the West [71].

\subsection{Who Owns the Forest?}

About $30 \%$ of America's timberland is publicly-owned (Figure 4). Public ownership trends by region follow the general trends already discussed. Due to federal land ownership being concentrated in the West, most of the public timberland is in the West. Regionally, larger percentages of the western timberlands are publicly-owned. Likewise, the opposite holds true with private lands. They tend to be concentrated in the East. This is especially true when noncorporate private land is considered; this ownership group includes family forests and they tend to be in the East.

Recent shifts in forest industry land ownership deserve discussion [72]. Private forestland and timberland owners are commonly broken down into forest industry owners 


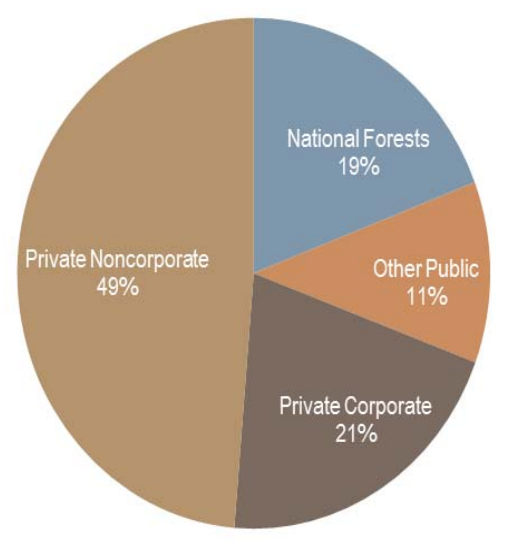

Figure 1. Public and private timberland by type of ownership in United States, 2007 [71].

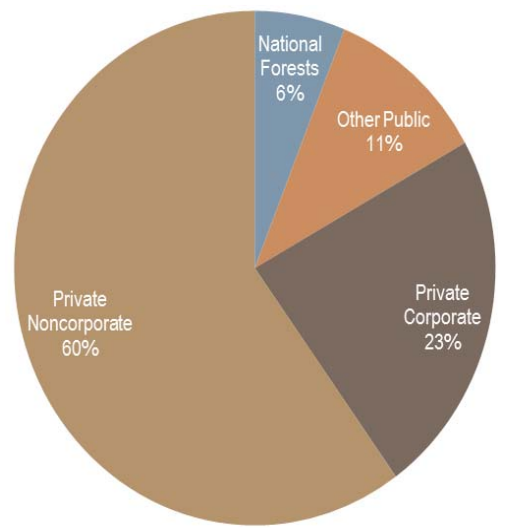

Figure 2. Public and private timberland in eastern United States, by ownership type, 2007 [71].

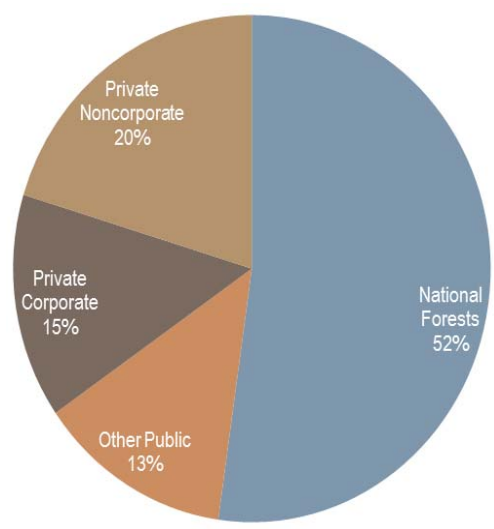

Figure 3. Public and private timberland in western United States, by ownership type, 2007 [71].

(these are corporations and other private groups that own forestland and own and operate primary wood-processing facilities) and nonindustrial private forest (NIPF) owners (these are families, individuals, corporations, and other private groups who own forestland, but do not own and operate a primary wood-processing plant). Family forest owners are a subset of NIPF owners [73].
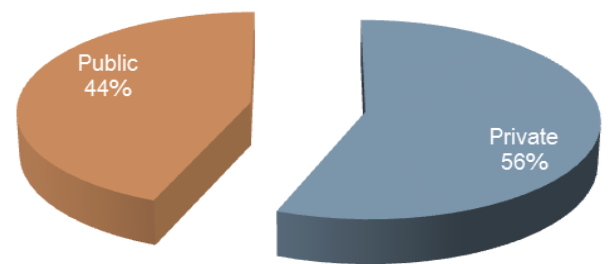

Figure 4. Public and private forestland in the United States, 2006 [73].

Over the last three decades, forest industry divested itself of much forestland. Timberland investment management organizations (TIMOs) purchased these properties to be managed for timber production and investor financial returns. Many of the forest industry firms that did not divest themselves of timberland instead restructured themselves so that ownership and control of their forestland was in a real estate investment trust (REIT), separate from ownership and control of their manufacturing facilities. This was a major transition in private timberland ownership in the United States and these lands are now included under private corporate owners.

How does all this affect forest management planning by the three organization types (forest industry, TIMOS and REITs)? How does this shift of ownership types impact future timber supplies, management behavior, and the foundations that control the planning process? First, in terms of forest management practices and intensity all three ownership types practice about the same level of forestry. All three are investment-oriented; all three have shareholders or investors who expect returns. TIMOs may have a shorter planning horizon, but still need to invest the capital to have a viable forest at the end of the investment term. TIMOs and REITs do have more flexible timber harvesting options than forest industry. Second, all three exist primarily to produce timber. All three manage for multiple objectives and make huge efforts to protect the environment, but all three are primarily profit-oriented. Third, TIMOs, with their shorter planning horizons, do have higher turnover of forestland and this has led to forest fragmentation. Fourth, TIMOs and REITs don't have the mill supply requirements of forest industry, so may be more willing to convert some of their holdings to non-forest uses. However, TIMOS and REITs also seem to be willing to protect environmentally-sensitive lands with conservation easements. This sometimes makes timber harvesting easier in areas with high public concern over the environment. Fifth, TIMOs and REITs appear to provide less funding for forestry research than forest industry did. Sixth, TIMOs and REITs seem less concerned with the general forestry community than forest industry was, based on involvement in professional organizations and contributions to the forestry profession.

Another USDA Forest Service ownership category is private noncorporate timberland, owned by individuals, 
partnerships, clubs, trusts, and Native Americans. Almost $90 \%$ of private noncorporate timberland is in the eastern United States, divided nearly equally between the North and the South. This category is mainly the small family forests. There are over 10 million family forest owners in the United States and their forest management objectives vary widely. At any point in time some family forest timberland will be unavailable for harvest, but these owners change over time and so do ownership objectives. Thus, timberland that is unavailable for harvest today may prove to be available in the future [73].

Publicly-owned timberland is mainly in the western United States, and the private timberland is mostly in the eastern United States. Major timberland regions are the South, Northeast, North Central, Pacific Northwest, and Intermountain regions. Private corporate (forest industry, TIMOs, and RIETs) are mainly in the South, North, Pacific Northwest, and North Central regions. Most private noncorporate owners (mainly family forest owners) are in the eastern United States [73].

There are about 35 to 40 million ha of forest industry, TIMO, and RIET timberland. In the past five years about 11 million ha of forest industry timberland changed hands in the United States. Another 4 million are predicted to change hands in the next decade. Family forest owners control about 100 million ha of timberland. Over $90 \%$ of the private noncorporate timberland is family forests. This is a huge portion of the private ownership with over 10 million owners with diverse management objectives. Family forests are crucial to the nation's timber supply and are another rapidly changing ownership category [73].

There are 171 million ha of private forestland; 56 million ha are corporate and 115 million ha are noncorporate (Figure 5). As a subset of forestland, there are about 144 million ha of timberland; 43 million ha are corporate and 101 million ha are noncorporate (Figure 6).

Family forests are often small tracts, as nearly threequarters are less than 8 ha in size. However, over a half million family forest owners control 40 ha or more. Plus, about 20,000 owners have tracts of over 400 ha in size. Seventy-two percent of family forests are in the eastern United States, where the productive timberland and private ownership is located. The states with the great-

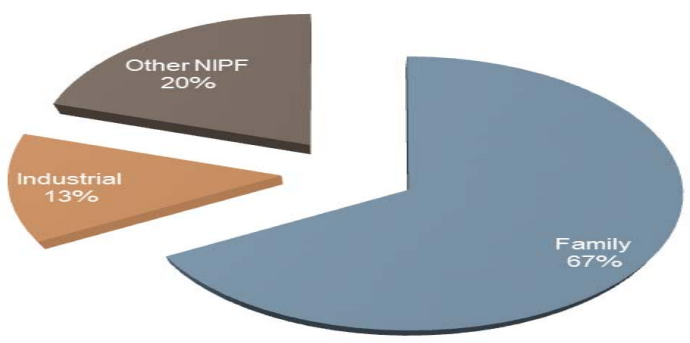

Figure 5. Private forestland in the United States, by ownership, 2006 [73].

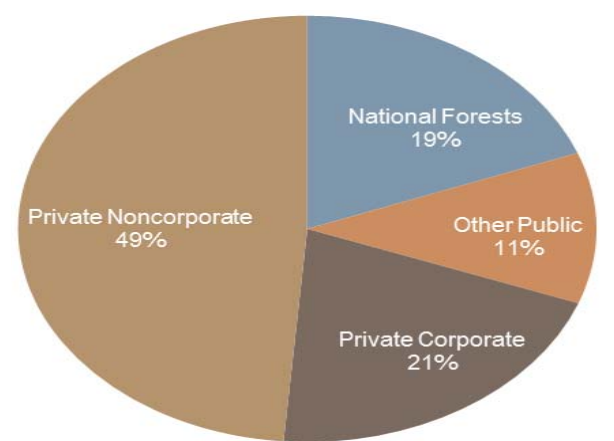

Figure 6. Timberland in the United States, by ownership, 2006 [73].

est area of private forestland, each with more than 6 million ha, are Alaska, Georgia, Alabama, Mississippi, Maine, Texas, North Carolina and Arkansas. The states with the greatest number of private owners, each with more than 500,000 owners, are New York, Tennessee, North Carolina, Georgia and Florida.

Seventy percent of American timberland is in private hands. Just over $20 \%$ is in private corporate hands. This is mainly forest industry, TIMOs, and REITS. These lands are managed intensively for timber management, usually under strong forest certification standards and environmental controls. The big player is the family forests at $35 \%$ of all forestland. These owners have a variety of management objectives and timber production does not top the list, at least when they are surveyed. Actual practice shows more timber harvests than surveys of intentions would indicate. These family forests play a crucial role in protection of America's forest lands and sustainability of long-term timber goals. Efforts to educate these family forest owners are important to forest sustainability and efforts to encompass these lands under forest certification programs would contribute greatly to forest sustainability goals [73].

\subsection{Who Does Forest Management Planning in United States?}

The intensity, management objectives emphasized, public participation levels, depth of analysis, plan structure, and management philosophy differ by the type of organization preparing the plan. Management plans can vary from simple to very complex documents. Public forestland and timberland are managed by government agencies and, thus, these public lands represent the largest single entity forestland managers in the nation. The public owns and controls almost $40 \%$ of the nation's forestland and nearly $31 \%$ of its timberland. The federal government controls $76 \%$ of the public forestland and $71 \%$ of the public timberland.

The USDA Forest Service manages $45 \%$ of the public forestland and $63 \%$ of the public timberland. This is $19 \%$ 
of total timberland, making the Forest Service the nation's largest timber manager. The Bureau of Land Management manages $15 \%$ of the public forestland and $4 \%$ of the public timberland. Both agencies prepare some of the most comprehensive forest resource management plans in the country [71,73]. There is a strong regional pattern in public ownership of forestland (Table 1). National forest and Bureau of Land Management forestland tends to be in the West. State, county, and municipal forestland is concentrated in the North.

The USDA Forest Service manages 60 million ha of forestland and, as subsets of that, 40 million ha of timberland, 11 million ha of reserved forest and 9 million ha of other forest. These lands undergo some of the most intense forest and natural resource planning activities of all forestlands in the nation. In terms of management plans, these are highly-developed, complex, and very public participation-oriented.

The Bureau of Land Management (BLM) administers about 104 million ha of land area. These public lands make up about $13 \%$ of the U.S. land area and more than $40 \%$ of land managed by the federal government. Most of these lands are in the western United States. The BLM manages about 23 million ha of commercial forests and woodlands. It also manages significant grazing permits and rangelands. Federal regulations require complex multiple-use management plans developed with high levels of public participation. The BLM is in the United States Department of Interior [71,73].

There are other major agencies in the Department of Interior that manage land. The Fish and Wildlife Service manages about 37 million ha, the National Park Service manages about 34 million ha, the Bureau of Reclamation manages about 4 million ha, and the Bureau of Indian Affairs manages about 28 million ha. Natural resource management objectives on these lands will center on agency priorities. For example, National Parks are reserved forestland, so management plans will stress nontimber resources and recreation opportunities.

The Department of Defense manages about 11 million ha of land. Obviously, land management is not its primary function. However, given the location of many of its holdings (bases in remote areas), it does manage much ecologically significant land. Some of its holdings have tremendous biological diversity. Thus, natural resource

Table 1. Regional distribution of forest land in United States by ownership type (percent), 2007 [71].

\begin{tabular}{cccc}
\hline Ownership Type & North & South & West \\
\hline National Forest & 10 & 12 & 78 \\
Bureau Land Management & 0 & 0 & 100 \\
Other Federal & 24 & 68 & 8 \\
Municipal County, State & 56 & 18 & 26 \\
\hline
\end{tabular}

management planning is an important function for maintaining these lands. Complex planning takes place on these lands.

State governments administer about 28 million ha of forestland and about 14 million ha of timberland (as a subset of forestland). Much of this land is managed in state forests or similar arrangements and involves detailed management planning, often with significant public participation. County and municipal governments manage about 4.5 million ha of forestland and about 4 million ha of timberland (as a subset of forestland). These forests are usually well-managed and a well-developed management plan commonly exists. These are public lands and management plans are usually subject to significant public participation [71,73].

Forest industry has been divesting itself of timberland over the last two decades, but still owns and controls significant forestland area. Most forestland owned by forest industry is timberland, as this owner group has strong timber production management and financial returns objectives. Most of this timberland is managed under a detailed, comprehensive forest resource management plan. While timber production is the reason most of forest industry owns forestland, most companies make a strong effort to practice professional forest stewardship and these forests tend to be managed for multiple-uses. Many forest industry companies have made strong environmental commitments. It is not unusual for environmentally-sensitive lands to be protected from timber harvest.

At the same time, forest industry purchased these forestlands with shareholder funds and they represent assets on a balance sheet. Often forest management planning will emphasize cash flows and rates of return. Thus, the planning process and resulting written plan often emphasize financial analysis concerns. The forest resource management plan will be a component of a larger business management plan and will be expected to contribute to overall company objectives. It is also likely to be detailed in terms of operational planning in order to achieve these objectives.

The nonindustrial private forest (NIPF) owners control over half again as much area as forest industry. So their importance is great. But who are they? The "p" stands for private, and the " $\mathrm{n}$ " means they are not forest industry lands, and they are not family forest owners. That leaves corporate private owners who are not part of forest industry. These are the corporate owners without timber processing facilities. Many corporations own land as part of their operations. Much of this land is managed with a profit motive, usually with strong environmental considerations, to enhance overall corporate returns. The TIMOs and REITs discussed earlier are major components of this ownership category. TIMOs and RIETs have 
traditionally been included in the NIPF category, but are now classified as part of the private corporate ownership category $[71,73]$.

As forest industry started to divest itself of timberland starting in the early 1980's, much of the land was purchased by investor groups to be managed for timber production and investor financial returns. Management planning and management intensity was similar to the forest industry that sold the land; TIMOs had the same type of financial objectives, so the forest was managed about the same as forest industry. TIMOS manage about 10 million ha worth about $\$ 30$ billion [72]. Examples of TIMO' are Hancock Timber Resource Group, RMK Timberlands, The Campbell Group, Resource Management Services, and Forest Investment Associates.

REITs were also discussed earlier. The three largest publicly-traded REITs are Plum Creek, Rayonier, and Potlatch. These three REITs own about 4.5 million ha of timberland. Plum Creek is the largest private landowner in the US at over 3 million ha. Generally these forestlands are managed with a profit motive for timber production. The firms tend to be environmentally sensitive and most planning considers multiple objectives. While public participation in the planning process is likely to be low, the firms will be sensitive to local management concerns and adjust their planning accordingly.

Family forests are the lynchpin to long-term sustainability of the nation's forests and a sustainable timber supply. About 11 million private forest owners control $56 \%$ of America's forestland. Family forest owners account for over 10 million (or 92\%) of these private forestland owners. That means family forest owners control $62 \%$ of the private forestland in the country, or $35 \%$ of all forestland. Over 10 million family forest owners equates to a huge population of owners and forest properties.

Sixty-one percent of family forest owners control tracts of less than 4 ha in size. Management of tracts that small is challenging. However, just over half of family forestland is in tracts of 40 ha or more. So, many of the family forests are small and difficult to manage, but many are large and often owners are active forest managers. Family forest owners receive advice, technical assistance, and financial assistance in managing their forest resources. Society can't ignore this huge portion of the nation's forestland. But which forest owners should the focus be on?

Most of the family forests are small and the cost of managing many small forests would be high. But would it be fair to concentrate assistance on the forest owners with larger properties (the same ones who likely have better financial positions than the owners of smaller properties)? Family forests have been a forest policy concern for over 100 years.
Some family forests can be quite large. The Land Report identifies the 100 largest private individual or family landowners in the country. Many of these holdings are ranches and used for grazing and hunting. Some are timberland holdings. Ted Turner owns over 800,000 ha and tops that list, but number two is a timberland holding. The former Sierra Pacific timberland holdings are owned by the Emmerson family and totals 688,000 ha. Number four is the Irving family timberland holdings in Maine of 486,000 ha. Four other families own over 200,000 ha of timberland. Over 2.8 million ha of timberland was owned by 15 of these families. Not all family forests are small [74].

The area controlled by family forest owners is huge. The type of management plan these owners have varies from none to detailed plans that consider financial, silvicultural, conservation, and operational issues. Only 4\% of family forest owners reported having a written management plan. Those same owners controlled $17 \%$ of the family forestland. Owners of larger family forests are much more likely to have a forest management plan than those with smaller forest area [73].

The lack of a management plan does not mean those same family forest owners do not receive professional forest management advice. Fourteen percent of family forest owners received forest management advice; those same owners controlled 37\% of family forests [73].

The forest management plans prepared for family forest owners vary by management objectives. Plans prepared by forestry commission foresters, service foresters, stewardship foresters, and the technical advice supplied by other natural resource professionals (water quality, wildlife, recreation) tend to be multiple-use oriented, stewardship-focused, and stress forest values of the state agencies that prepared them. Consulting foresters and forest industry landowner assistance foresters prepare forest management plans for landowners with a financial interest. These plans tend to stress forest management and often are timber production and profit-motivated.

These large family forest holdings illustrate the challenge of forest management planning for this ownership. The family forest owners are a diverse group of people, with very diverse management objectives, and very diverse financial resources to accomplish these objectives. Forest certification systems that manage to accept this diversity will prove to be a huge asset in achieving higher levels of forest management planning on these family forests. Private property rights give family forest owners huge choices in management direction and forest regulation is limited in achieving enhanced forest sustainability. Financial incentives, technical assistance, and education programs have been shown to influence these forest owners; other incentives, like forest certification, have provided better markets for timber products and 
have produced this same influence.

The management objectives of the forest owners determine the type of forest management planning that will take place on any forestland. Public agencies tend to have complex, detailed procedures, planning processes, and plans. Public participation is a hallmark of the public forest planning process. Private forestland is managed with vast differences in forest owner's objectives and forest planning on private lands varies vastly, from very complex to none at all. Again, management objectives control the process. Forestland and timberland ownership patterns across the country give valuable insights into the type of forest management planning practiced, as there are clear differences in planning across these ownerships.

\section{Conclusions}

Forest resource management planning in the United States began in the late nineteenth century. It had a framework that emigrated into American forestry from Europe. Early American forest management plans were highly structured documents with a well-established framework. The forest planning was based on the sustained yield model that also emigrated in from Europe. This meant that a set of expectations or requirements were integral to the planning process. We described these requirements and discussed how they had remained essentially unchanged over time.

The sustained yield model has evolved into a sustainable forest management model and multiple forest management objectives and multiple forest resources are now the norm. Thus, the content, plan emphasis, and plan organization have changed over time. However, the fundamental requirements of forest management plan development have not changed. We discuss who owns the forest and who prepares the forest management plans. Forest management plans differ between owner types, especially in complexity and preparation effort. Different types of forest management plans will come from different owners, but the set of basic requirements will tend to remain consistent.

\section{REFERENCES}

[1] K. P. Davis, "Forest Management: Regulation and Valuation,” 2nd Edition, McGraw-Hill Book Company, New York, pp. 292-311.

[2] H. A. Meyer, A. B. Recknagel, D. D. Stevenson and R. A. Bartoo, "Forest Management," 2nd Edition, The Ronald Press Company, New York, 1961, pp. 163-275.

[3] T. J. Straka, "Forest Resource Management Plans-A Landowner-Oriented Approach," Journal of Natural Resources and Life Sciences Education, Vol. 22, No. 2, 1993, pp. 111-115.

[4] H. H. Chapman, “Forest Management,” J. B. Lyon Com- pany, Albany, 1931.

[5] W. A. Leuschner, "Introduction to Forest Resource Management,” John Wiley \& Sons, New York, 1984, pp. 253-269.

[6] B. T. Parry, H. J. Vaux and N. Dennis, "Changing Perceptions of Sustained-Yield Policy on the National Forests,” Journal of Forestry, Vol. 81, No. 3, 1983, pp. 150154.

[7] H. K. Steen, "History of Sustained Yield Forestry: A Symposium,” Forest History Society, Durham, 1984.

[8] P. Bettinger, K. Boston, J. P. Siry and D. L. Grebner, "Forest Management and Planning," Academic Press, Burlington, 2009.

[9] G. Pinchot, "Biltmore Forest, the Property of Mr. George W. Vanderbilt: An Account of Its Treatment, and the Results of the First Year's Work,” The Lakeside Press, Chicago, 1893.

[10] I. F. Eldredge, "Management Plans with Special Reference to the National Forests,” United States Department of Agriculture Miscellaneous Publication 11, Government Printing Office, Washington DC, 1928.

[11] F. E. Olmsted, "A Working Plan for Forest Lands Near Pine Bluff, Arkansas,” United States Department of Agriculture Bureau of Forestry Bulletin Number 32, Government Printing Office, Washington DC, 1902.

[12] T. H. Sherrard, “A Working Plan for Forest Lands in Hampton and Beaufort Counties, South Carolina,” United States Department of Agriculture Bureau of Forestry Bulletin Number 43, Government Printing Office, Washington DC, 1903.

[13] D. N. Bengston, T. J. Webb and D. P. Fan, "Shifting Forest Value Orientations in the United States, 1989-2001: A Computer Content Analysis,” Environmental Values, Vol. 13, No, 3, 2004, pp. 373-392.

http://dx.doi.org/10.3197/096327104323312734

[14] T. J. Straka, "Recognition of Wildlife Amenity Values in Defining the Small Forest Ownership Problem in the United States: A Literature Review," Wildlife Biology in Practice, Vol. 7, No. 1, 2011, pp. 1-22. http://dx.doi.org/10.2461/wbp.2011.7.1

[15] L. S. Davis, K. N. Johnson, P. Bettinger and T. E. Howard, "Forest Management: To Sustain Ecological, Economic, and Social Values,” 4th Edition, Waveland Press, Inc., Long Grove, 2001.

[16] W. B. Kessler, H. Salwasser, C. W. Cartwright Jr. and J. A. Caplan, "New Perspectives for Sustainable Natural Resources Management,” Ecological Applications, Vol. 2, No. 3, 1992, pp. 221-225. http://dx.doi.org/10.2307/1941856

[17] W. A. Duerr, "Introduction to Forest Resource Economics,” McGraw-Hill, Inc., New York, 1993.

[18] J. L. Innes, G. M. Hickey and H. F. Hoen, "Forestry and Environmental Change; Socioeconomic Political Dimensions,” CABI Publishing, New York, 2005. http://dx.doi.org/10.1079/9780851990026.0000

[19] USDA Forest Service, "Forest Stewardship Program National Standards and Guidelines,” USDA Forest Service, State and Private Forestry, Cooperative Forestry, Wash- 
ington DC, 2009.

[20] D. R. Russell Jr. and S. Stein, "Planning for Forest Stewardship: A Desk Guide,” USDA Forest Stewardship Program FS-733, Department of Agriculture (USDA), Washington DC, 2002.

[21] Pinchot Institute for Conservation, “A Comparison of Guidelines for the Forest Stewardship Program and Other Standards of Sustainable Forest Management," Pinchot Institute for Conservation, Washington DC, 2008.

[22] F. M. Melfi, T. J. Straka, A. P. Marsinko and J. L. Baumann, "Landowner Attitudes toward South Carolina's Forest Stewardship Program," Southern Journal of Applied Forestry, Vol. 21, No. 4, 1997, pp. 158-163.

[23] T. G. Thrift, T. J. Straka, A. P. Marsinko and J. L. Baumann, "Forest Resource Management Plans: Importance of Plan Components to Nonindustrial Private Forest Landowners in South Carolina," Southern Journal of Applied Forestry, Vol. 21, No. 4, 1997, pp. 164-167.

[24] S. E. Daniels, M. A. Kilgore, M. G. Jacobson, J. L. Greene and T. J. Straka, "Examining the Compatibility between Forestry Incentive Programs in the US and the Practice of Sustainable Forest Management,” Forests, Vol. 1, No. 1, 2010, pp. 49-64. http://dx.doi.org/10.3390/f1010049

[25] M. A. Kilgore, J. L. Greene, M. G, Jacobson, T. J. Straka and S. E. Daniels, “The Influence of Financial Incentives in Promoting Sustainable Forestry on the Nation's Family Forests,” Journal of Forestry, Vol. 105, No. 4, 2007, pp. 184-191.

[26] B. Cashore, G. Auld and D. Newson, “Governing through Markets: Forest Certification and the Emergence of NonState Authority," Yale University Press, New Haven, 2004.

[27] E. Hanson, R. Fletcher, B. Cashore and C. McDermott, "Forest Certification in North America," Oregon State University Extension Service, Corvallis, 2006.

[28] C. Maser and W. Smith, "Forest Certification in Sustainable Development: Healing the Landscape,” CRC Press, Boca Raton, 2001.

[29] E. Rametsteiner and M. Simula, "Forest CertificationAn Instrument to Promote Sustainable Forest Management," Journal of Environmental Management, Vol. 67, No. 1, 2003, pp. 87-98. http://dx.doi.org/10.1016/S0301-4797(02)00191-3

[30] D. B. Lindenmayer and J. F. Franklin, "Towards Forest Sustainability,” Island Press, Washington DC, 2003.

[31] B. Shindler and L. A. Cramer, "Shifting Public Values for Forest Management: Making Sense of Wicked Problems," Western Journal of Applied Forestry, Vol. 14, No. 1, 1999, pp. 28-34.

[32] V. M. Vianna, J. Erwin, R. Z. Donovan, C. Elliott and H. Gholz, "Certification of Forest Products: Issues and Perspectives,” Island Press, Washington DC, 1996.

[33] K. Vogt, B. C. Larson, J. C. Gordon, D. J. Vogt and A. Fanzeres, "Forest Certification: Roots, Issues, Challenges, and Benefits,” CRC Press, Boca Raton, 2000.

[34] M. Williams, "Deforesting the Earth: From Prehistory to Global Crisis, an Abridgement,” Kluwer Academic Pub- lishers, Dordrecht, 2006.

http://dx.doi.org/10.7208/chicago/9780226899053.001.00 $\underline{01}$

[35] P. Perera and R. P. Vlosky, "A History of Forest Certification,” Forest Products Development Center Working Paper No. 71, Louisiana State University, Baton Rouge, 2006.

[36] D. W. Floyd, "Forest Sustainability: The History, the Challenge, the Promise," The Forest History Society, Durham, 2002.

[37] D. W. Floyd, S. L. Vonhof and H. E. Seyfand, "Forest Sustainability: A Discussion Guide for Professional Resource Managers,” Journal of Forestry, Vol. 99, No. 2, 2001, pp. 8-28.

[38] D. Klooster, "Environmental Certification of Forests: The Evolution of Environmental Governance in a Commodity Network,” Journal of Rural Studies, Vol. 21, No. 4, 2005, pp. 403-417. http://dx.doi.org/10.1016/j.jrurstud.2005.08.005

[39] T. J. Straka and P. A. Layton, "Natural Resource Management: Life Cycle Assessment and Forest Certification and Sustainability Issues,” Sustainability, Vol. 2, No. 2, 2010, pp. 604-621. http://dx.doi.org/10.3390/su2020604

[40] C. M. Watts, L. S. Pile and T. J. Straka, "Sustainability and Forest Certification as a Framework for a Capstone Forest Resource Management Plans Course,” Open Journal of Forestry, Vol. 2, No. 3, 2012, pp.159-166. http://dx.doi.org/10.4236/ojf.2012.23019

[41] P. B. Durst, P. J. McKenzie, C. L. Brown and S. Appanah, "Challenges Facing Certification and Eco-Labeling of Forest Products in Developing Countries,” International Forestry Review, Vol. 8, No. 2, 2006, pp. 193-200. http://dx.doi.org/10.1505/ifor.8.2.193

[42] V. A. Sample and S. Anderson, "Common Goals for Sustainable Forest Management: Divergence and Reconvergence of American and European Forestry,” Forest History Society, Durham, 2008.

[43] V. A. Sample and R. A. Sedjo, "Sustainability in Forest Management: An Evolving Concept," International Advances in Economic Research, Vol. 2, No. 2, 1996, pp. 165-173. http://dx.doi.org/10.1007/BF02295056

[44] B. Holvoet and B. Muys, "Sustainable Forest Management Worldwide: A Comparative Assessment of Standards," International Forestry Review, Vol. 6, No. 2, 2004, pp. 99-122.

http://dx.doi.org/10.1505/ifor.6.2.99.38388

[45] K. von Gadow, T. Pukkala and M. Tomé, "Sustainable Forest Management,” Kluwer Academic Publishers, Dordrecht, 2002.

[46] G. T. McDonald and M. B. Lane, "Converging Global Indicators for Sustainable Forest Management," Forest Policy and Economics, Vol. 6, No. 1, 2004, pp. 63-70. http://dx.doi.org/10.1016/S1389-9341(02)00101-6

[47] C. Fischer, F. Aguilar, P. Jawahar and R. Sedjo, "Forest Certification: Toward Common Standards," Resources for the Future, Washington DC, 2005.

[48] World Commission on Forests and Sustainable Development, "Our Forests, Our Future,” Cambridge University 
Press, Cambridge, 1999.

[49] C. D. Oliver, "Sustainable Forestry: What Is It? How Do We Achieve It?” Journal of Forestry, Vol. 101, No. 5, 2003, pp. 8-14.

[50] T. J. Straka, "Evolution of Sustainability in American Forest Resource Management Planning in the Context of the American Forest Management Textbook," Sustainability, Vol. 1, No. 4, 2009, pp. 838-854. http://dx.doi.org/10.3390/su1040838

[51] J. Buongiorno and J. K. Gilless, "Decision Methods for Forest Resource Management," Academic Press, Burlington, 2003.

[52] W. A. Leuschner, "Forest Regulation, Harvest Scheduling, and Planning Techniques,” John Wiley \& Sons, Inc., New York, 1990.

[53] W. A. Duerr, "Fundamentals of Forestry Economics," McGraw-Hill Book Company, New York, 1960.

[54] W. D. Klemperer, "Forest Resource Economics and Finance,” McGraw Hill, Inc., New York, 1996.

[55] T. J. Straka and C. J. Childers, “'Consulting Foresters' View of Professional Forestry Education,” Journal of Natural Resources and Life Sciences Education, Vol. 35, No. 1, 2006, pp. 48-52.

[56] R. A. Sedjo, "Investments in Forestry: Resources, Land Use, and Public Policy,” Westview Press, Boulder, 1985.

[57] F. C. Zinkhan, W. R. Sizemore, G. H. Mason and T. J. Ebner, "Timberland Investments: A Portfolio Perspective,” Timber Press, Portland, 1992.

[58] M. P. Washburn, S. B. Jones and L. A. Nielsen, "Nonindustrial Private Forest Landowners: Building the Business Case for Sustainable Forestry,” Island Press, Washington DC, 1999.

[59] T. J. Straka, “Taxonomic Review of Classical and Current Literature on the Perennial American Family Forest Problem," Forests, Vol. 2, No. 3, 2011, pp. 660-706. http://dx.doi.org/10.3390/f2030660

[60] A. B. Recknagel, "The Theory and Practice of Working Plans (Forest Organization),” John Wiley \& Sons, New York, 1913.

[61] C. Maser, "Sustainable Forestry: Philosophy, Science, and Economics,” St. Lucie Press, Delray Beach, 1994.

[62] A. E. Patterson, “Technique of Forest Management Plan Preparation,” Self-published, Athens, 1960.

[63] M. Webb, “The Forest Management Plan: Key to the Future,” Forest Landowner, Vol. 60, No. 4, 2001, pp. 2325.

[64] E. C. Frazer III, “Effective Forest Management,” Forest Farmer, Vol. 42, No. 5, 1983, pp. 18-21.

[65] E. C. Frazer III and P. Hodgkins, "Timber Management Plans for Modest-Sized Landowners," Forest Farmer, Vol. 36, No. 5, 1977, pp. 11-13.

[66] L. K. Larson, “Managing Small Forest Holdings,” Forest Farmer, Vol. 33, No. 2, 1973, pp. 9, 28.

[67] T. J. Straka, "Forest Management Plans for Small Holdings,” Forest Landowner, Vol. 56, No. 5, 1997, pp. 34-35, 38-39.

[68] B. Hatcher, “The Management Plan,” In: M. J. Wallace and A. Londo, Eds., Managing the Family Forest in Mississippi, Mississippi State University, Starkville, 2008, pp. 8-15.

[69] S. Loveland, "Good Forestry Starts with a Good Plan," Forest Landowner, Vol. 62, No. 3, 2003, pp. 14-15.

[70] R. M. Shaffer, “A Guide to Harvest Planning,” The Consultant, Vol. 37, No. 3, 1992, pp. 12-15.

[71] W. B. Smith, P. D. Miles, C. H. Perry and S. A. Pugh, "Forest Resources of the United States, 2007," General Technical Report WO-78, USDA Forest Service, Washington DC, 2009.

[72] J. E. Hatcher Jr., T. J. Straka, R. A. Harper and T. O. Adams, "Shifting Private Timberland Ownership in South Carolina: Implications for Management Intensity," Open Journal of Forestry, Vol. 2, No. 4, 2012, pp. 279-285. http://dx.doi.org/10.4236/ojf.2012.24035

[73] B. J. Butler, "Family Forest Owners of the United States, 2006,” General Technical Report NRS-27, USDA Forest Service, Northern Research Station, Newtown Square, 2008.

[74] The Land Report, "Largest 100 Owners," The Land Report, Vol. 4, No. 3, 2010, pp. 37-54. 